\title{
Apparel buying behaviour of college boys and girls in relation to visual merchandising: Acomparative study
}

\section{Manpreet Kaur and Rupal Babel}

Received: 18.06.2019; Revised: 30.10.2019; Accepted: 14.11.2019

See end of the paper for authors' affiliations Manpreet Kaur

Department of Textiles and Apparel Designing, College of

Home Science, Maharana Pratap University of Agriculture and

Technology, Udaipur (Rajasthan) India

Email : mannukhinda08@gmail.

com
ABSTRACT : Visual merchandising can be defined as everything the customer sees, both exterior and interior, that creates a positive image of a business and results in attention, interest, desire and action on the part of the customer. In India College students are one of the most attractive segments as they have their own attitude, personality, perception and beliefs based on their prior shopping experiences. Boys and girls due to their different upbringing and socialization along with various other social, biological, and psychological factors depict different types of behaviour at various situations. The present study was undertaken to find out the role of visual merchandising on apparel buying behaviour of college students. To achieve the objective of the current study, survey was carried out on 180 college students ( 90 boys and 90 girls) between the age ranges of 25-35 years of Udaipur city. Questionnaire method was used for data collection. Maximum boy's preferred to buy their apparels from exclusive showrooms whereas maximum girls preferred to buy their apparels from online buying and shopping malls. Majority of boys and girls ( $72.2 \%$ and $82.2 \%)$ stated that effective visual merchandising induces impulsive buying. Both respondents (boys $75.5 \%$ and girls $80 \%$ ) agreed that their final buying decision is affected by visuals and display of apparels.

KEY WORDS: Visual merchandising

- HOW TO CITE THIS PAPER : Kaur, Manpreet and Babel, Rupal (2019). Apparel buying behaviour of college boys and girls in relation to visual merchandising: A comparative study. Asian J. Home Sci., 14 (2) : 403-406, DOI: 10.15740/HAS/AJHS/14.2/403-406. Copyright@ 2019: Hind Agri-Horticultural Society. 